\title{
METODE PEMBELAJARAN AKIDAH AKHLAK MI/SD
}

\author{
Susiba \\ Program Studi Pendidikan Guru Madrasah Ibtidaiyah, UIN Sultan Syarif Kasim Riau \\ e-mail:Ssusiba@yahoo.com
}

\begin{abstract}
ABSTRAK. This study uses the right method in learning Islamic MI/SD morals, because Islamic material gives a lot of things that are abstract, while new elementary children who can think concretely. This research was conducted to learn appropriate learning methods in learning MI/SD moral creed. The research method is a literature review, the source of data using primary and secondary data sources, and using data analysis techniques (content analysis). In this study found methods that are relevant to the learning of Islamic MI/SD A are: (1) Articulation Game Method, (2) Role playing method (3) Snowball throwing game (4) Lecture method (7) Question and Answer method (8) Mind Mapping Games (9) Sociodrama method (10) Demonstration method) (10) Method of analogizing something abstract into a concrete writing.
\end{abstract}

Kata kunci: Learning Methods, Moral Code, MI / Elementary School.

\section{PENDAHULUAN}

Pembelajaran adalah proses interaksi antara peserta didik dengan pendidik dan sumber belajar pada suatu lingkungan belajar. Pembelajaran merupakan bantuan yang diberikan pendidik agar dapat terjadi proses pemilihan ilmu dan pengetahuan, penguasaan kemahiran dan tabiat, serta pembentukan sikap dan kepercayaan pada peserta didik. Muhaimin (2001:145) menyatakan bahwa pembelajaran terkait dengan bagaimana (how to) membelajarkan siswa atau bagaimana membuat siswa dapat belajar dengan mudah dan terdorong atas kemauannya sendiri untuk mempelajari apa (what to) yang teraktualisasikan dalam kurikulum sebagai kebutuhan (needs) peserta didik.

Dalam pembelajaran seorang guru harus memperhatikan berbagai aspek aspek yang terkait di dalamnya, dan salah satunya adalah siswa. Guru harus memahami bahwa kemampuan daya serap siswa dalam menangkap pelajaran berbeda-beda, oleh karena itu guru harus menggunakan berbagai cara agar proses pembelajaran dapat berjalan secara efektif dan efisien serta mengena pada tujuan yang diharapkan. Salah satu cara yang dapat dipergunakan oleh guru yaitu menggunakan berbagai teknik-teknik penyajian pelajaran atau yang biasa disebut metode mengajar.

Selanjutnya, Fathurahman (2011:55) menjelaskan bahwa metode mengajar adalah cara-cara menyajikan bahan pelajaran kepada siswa untuk tercapainya tujuan yang telah ditetapkan. Metode pembelajaran merupakan cara untuk melakukan atau menyajikan, menguraikan memberi contoh dan memberi latihan isi pelajaran kepada siswa untuk 
mencapai tujuan tertentu, sinkronisasi antara metode dengan kemampuan yang akan dicapai berdasarkan indikator yang telah dirancang atau disepakati oleh guru atau guru bersama-sama siswa. Nantinya diharapakan guru dapat memilih metode apa yang paling tepat untuk mempertimbangkan jumlah siswa, alat, fasilitas, biaya dan waktu.

Penggunaan metode pembelajaran disetiap mata pelajaran sangat penting, karena tidak semua metode pembelajaran tepat untuk semua penyampaian, waktu kondisi dan bidang studi. Salah satu penentu dalam kegiatan belajar mengajar adalah metode. Dalam setiap proses pembelajaran termasuk pembelajaran aqidah akhlak. Metode memiliki kedudukan yang penting dalam Upaya pencapaian tujuan pembelajaran. Pengalaman membuktikan bahwa kegagalan pembelajaran salah satunya disebabkan oleh pemilihan metode yang kurang tepat. Karena itu metode dapat mempengaruhi jalannya kegiatan belajar mengajar.

Sebagai salah satu komponen pembelajaran, metode memiliki peranan yang tidak kalah pentingnya dengan komponen lainnya dalam kegiatan belajar mengajar. Tidak ada satupun kegiatan belajar mengajar yang tidak menggunakan metode dalam menyampaikan pelajarannya. Di samping itu, penggunaan metode yang tepat akan sangat membantu dalam usaha mencapai tujuan pendidikan. Kedudukan metode dalam proses belajar mengajar adalah sebagai alat motivasi ekstrinsik, sebagai strategi pembelajaran dan sebagai alat untuk mencapai tujuan.

Sementara itu akidah akhlak merupakan salah satu mata pelajaran yang ada dalam program pendidikan di Madrasah sebagaimana yang tercantum dalam kurikulum pendidikan dasar berciri khas agama Islam. Mata pelajaran Aqidah Akhlak merupakan mata pelajaran yang bertujuan untuk menumbuhkan dan meningkatkan keimanan peserta didik yang diwujudkan dalam akhlaknya yang terpuji, melalui pemberian dan pemupukan pengetahuan, penghayatan pengalaman serta pengalaman peserta didik tentang aqidah dan akhlak Islam.

Demikian mulianya tujuan pembelajaran akidah akhlak tersebut, jika guru menyampaikan pembelajaran dengan metode yang kurang tepat, tentu tujuan tersebut tidak akan tercapai secara maksimal. Oleh karena itu penulis tertarik untuk mengupas masalah ini dengan judul "Metode Pembelajaran Akidah Akhlak Berdasarkan Karakteristik Siswa MI/SD".

\section{METODOLOGI}

Metode penelitian ini adalah kajian pustaka atau studi kepustakaan yaitu berisi teori teori yang relevan dengan masalah-masalah penelitian. Adapun masalah pada penelitian ini adalah untuk mengetahui "METODE PEMBELAJARAN AKIDAH AKHLAK MI/SD"

Pada bagian ini dilakukan pengkajian mengenai konsep dan teori yang digunakan berdasarkan literatur yang tersedia, terutama dari artikel-artikel yang dipublikasikan dalam berbagai jurnal ilmiah. Kajian pustaka berfungsi untuk membangun konsep atau teori yang menjadi dasar studi dalam penelitian.

Kajian pustaka atau studi pustaka merupakan kegiatan yang diwajibkan dalam penelitian, khususnya penelitian akademik yang tujuan utamanya adalah mengembangkan 
aspek teoritis maupun aspek manfaat praktis. Sehingga dengan menggunakan metode penelitian ini penulis dapat dengan mudah menyelesaikan masalah yang hendak diteliti.

\section{Metode Pengumpulan Data}

Adapun metode pengumpuluan data penelitian ini diambil dari sumber data, Yang dimaksud sumber data dalam penelitian adalah subjek dari mana data dapat diperoleh. Apabila peneliti menggunakan dokumentasi, maka dokumen atau catatanlah yang menjadi sumber data, sedangkan isi catatan subjek penelitian atau variable penelitian. Dalam penulisan skripsi ini sumber data yang akan peneliti gunakan yaitu : (a). Sumber Primer (b). Sumber Sekunder.

\section{Teknik Analisa Data}

Setelah keseluruhan data terkumpul maka langkah selanjutnya penulis menganalisa data tersebut sehingga ditarik suatu kesimpulan. Untuk memperoleh hasil yang benar dan tepat dalam menganalisa data, penulis menggunakan teknik analisis isi.Analisis isi (Content Analysis) adalahpenelitian yang bersifat pembahasan mendalam terhadap isi suatu informasi tertulis atau tercetak di media massa.

Analisis isi dapat digunakan untuk menganalisa semua bentuk komunikasi, baik surat kabar, berita radio, iklan televisi maupun semua bahan dokumentasi yang lainnya. Sedangkan kaitannya dengan pembahasan yaitu sebagai salah satu upaya penulis dalam memudahkan pemahaman dengan cara menganalisa kebenarannya melalui pendapat para ulama yang kemudian diambil makna dan intisari dari pendapat para ulama tersebut, yang berkenaan dengan sedekah.

Adapun langkah- langkah strategis dalam penelitian analisis isi, sebagai berikut : Pertama, Penetapan desain atau model penelitian. Disini ditetapkan beberapa media, analisis perbandingan atau korelasi, objeknya banyak atau sedikit dan sebagainnya. Kedua, pencarian data pokok atau data primer, yaitu teks sendiri. Sebagai analisis isi, teks merupakan objek yang pokok, bahkan terpokok. Pencarian dapat dilakukan dengan menggunakan lembar formulir pengamatan tertentu yang sengaja dibuat untuk keperluan pencarian data tersebut. Ketiga, pencarian pengetahuan konstektual agar penelitian yang dilakukan tidak berada diruang hampa, tetapi terlihat kait-mengait dengan faktor- faktor lain

\section{HASIL PENELITIAN}

\section{Ruang Lingkup Materi Pembelajaran Akidah Akhlak MI/SD}

Pada dasarnya, Isi/materi kurikulum pada hakikatnya adalah semua kegiatan dan pengalaman yang dikembangkan dan disusun dalam rangka mencapai tujuan pendidikan. Secara umum, isi kurikulum itu dapat dikelompokkan menjadi tiga bagian, yaitu: (a). Logika: yaitu pengetahuan tentang benar salah (b). Etika: yaitu pengetahuan tentang baik buruk, nilai, dan moral (c). Estetika: yaitu pengetahuan tentang indah-jelek, yang ada nilai seni.

Demikian juga pemilihan isi kurikulum dipertimbangkan dengan kriteria sebagai berikut: (a). Sesuai dengan tujuan yang ingin dicapai (b). Sesuai dengan tingkat 
perkembangan peserta didik (c). Bermanfaat bagi peserta didik, masyarakat, dunia kerja, bangsa, dan negara, baik untuk masa sekarang maupun masa yang akan dating. (d). Sesuai dengan perkembangan ilmu pengetahuan dan teknologi.

Berdasarkan Standar Kompetensi Lulusan, Standar Kompetensi dan Kompetensi Dasar, secara lebih spesifik, mata pelajaran Akidah akhlak di Madrasah Ibtidaiyah meliputi empat aspek yaitu aspek akidah (keimanan), aspek akhlak, aspek adab Islami, dan aspek keteladanan.

Aspek Akidah

- Kalimat Thayyibah sebagai materi pembiasaan, meliputi: bacaan Tablil, Basmalah, Tabmid, Tasbih, Takbir, Ta'awud, Salam, Shalawat, Tarji', Istigfar, dan sebagainya.

- Al-asma al-Husna sebagai materi pembiasaan, meliputi Al-abad, al-Hamid, asy-Syakur, alQudus, ash-Shomad, al-'Adhim, al-Karim, al-Kabir, al-Malik, dan sebagainya.

- Iman kepada Allah dengan pembuktian sederhana melalui kalimat Thoyyibah, alAsma al-Husna dan pengenalan terhadap shalat lima waktu sebagai manisfetasi iman kepada Allah.

- Meyakini rukun iman (Iman kepada Allah, Malaikat, Kitab, Rasul dan hari akhir serta Qadla dan Qadar Allah).

Aspek Akhlak

- Pembiasaan akhlakul karimah, yaitu: disiplin, hidup bersih, ramah, sopan-santun, syukur nikmat, hidup sederhana, rendah hati, jujur, rajin, percaya diri, kasih sayang, taat, rukun, tolong-menolong, hormat dan patuh, siddiq, amanah, tablig, fathonah, tanggung jawab, adil, bijaksana, teguh pendirian, dermawan, optimistis, qona'ah, tawakal, kesederhanaan, toleransi, dan cinta.

- Menghindari akhlak sayiah (madzmumah) secara berurutan disajikan pada tiap semester dan jenjang kelas, yaitu: hidup kotor, berbicara jorok/kasar, bohong, sombong, malas, durhaka, khianat, iri, dengki, membangkang, munafik, hasud, kikir, serakah, pesimis, marah, fasik dan murtad.

Aspek adab Islami

- Adab terhadap diri sendiri, yaitu adab mandi, tidur, buang air besar/kecil, berbicara, meludah, berpakaian, makan-minum, belajar dan bermain.

- Adab terhadap Allah, yaitu adab di masjid, mengaji, dan beribadah. 
- Adab kepada sesama, yaitu kepada orang tua, saudara, guru, teman, dan tetangga serta manusia secara umum, baik satu agama ataupun tidak.

- Adab terhadap lingkungan, yaitu kepada binatang dan tumbuhan, di tempat umum dan di jalan.

Aspek Kisah Teladan

Aspek ini meliputi: kisah Nabi Ibrahim mencari Tuhan Nabi Sulaiman dengan tentara semut, masa kecil Nabi Muhammad SAW, masa remaja Nabi Muhammad SAW. Nabi Ismail, Kan’an, kelicikan saudara-saudara Nabi Yusuf as., Tsa'labah, Masithah, Ulul Azmi, Qarun, Nabi Sulaiman dan umatnya, Ashabul Kahfi, Nabi Yunus dan Nabi Ayub. Materi kisah-kisah teladan ini disajikan sebagai penguat terhadap isi materi yaitu akidah dan akhlak, sehingga tidak ditampilkan dalam standar kompetensi, tapi ditampilkan dalam kompetensi dasar dan indikator.

Ada sejumlah materi Akidah Akhlak di SD/MI dari kelas I-VI dalam kompetensi dasar mata pelajaran PAI SD/MI berdasarkan kurikulum 2013. Materi-materi tersebut di antaranya.

- Kelas I yaitu: Rukun Iman, Syahadat Tauhid dan Rasul, Asmaul Husna 1 (آلْوَا حِدُ, آلْخَا لق), Berakhlak Terpuji dan Beradab Islami, Akhlak Tercela 1 (Hidup Kotor, Bohong atau Dusta, Berbicara Kotor), Kalimat Tayibah (Basmalah), Asmaul Husna 2 ( آلرَّحْمَنُ,

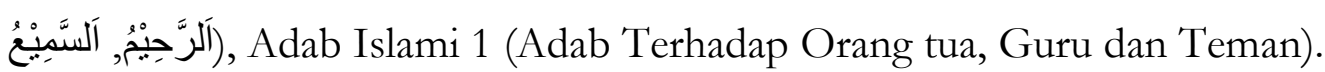

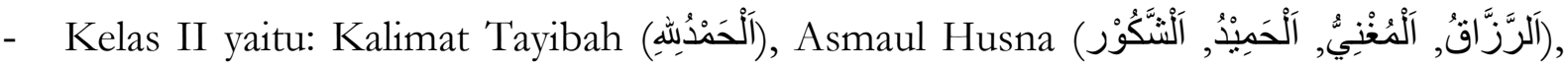
Berakhlak Terpuji dan Beradab Islami (Berakhlak Terpuji dan Beradab Islami),

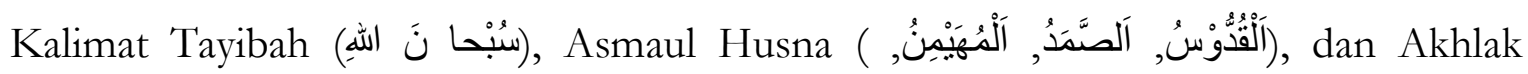
Tercela (Pemalas).

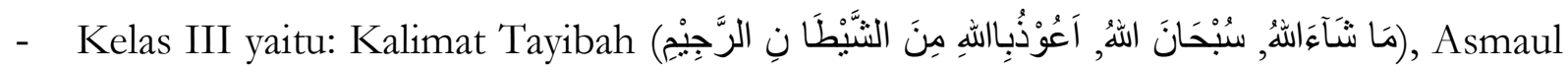

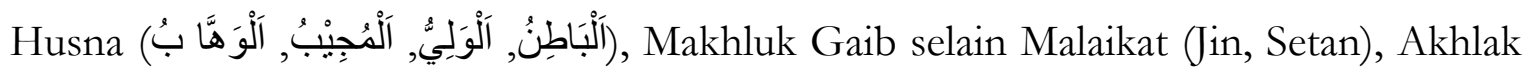
Terpuji (Rukun dan Tolong Menolong; Akhlak Terhadap Saudara), Akhlak Tercela (Khianat, Dengki, dan Iri).

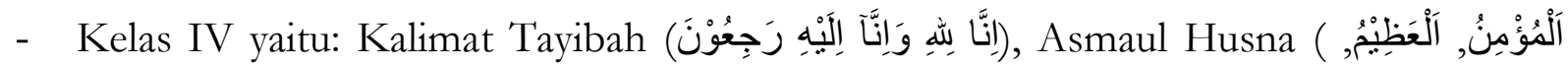

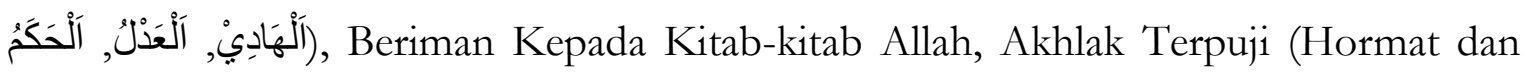
Patuh; Tabah dan Sabar Menghadapi Cobaan Melalui Kisah Masyitah; Salam), Akhlak 
Tercela (Kisah Tsa'labah, Akhlak Tercela yang Dimiliki Tsa'labah, Munafik), Beriman Kepada Rasul-Rasul Allah.

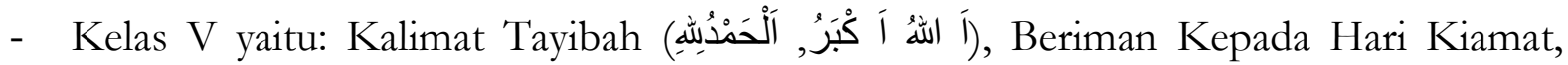
Akhlak Terpuji (Optimis, Qana'ah, dan Tawakkal; Adab di Tempat Ibadah dan Tempat Umum; Teguh Pendirian dan Dermawan); Hidup Bertetangga dan Bermasyarakat; dan Akhlak Tercela (Kikir, Serakah, dan Kisah Al-Qur'an), Asmaul

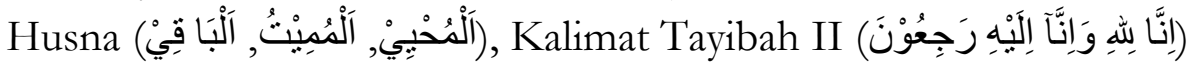

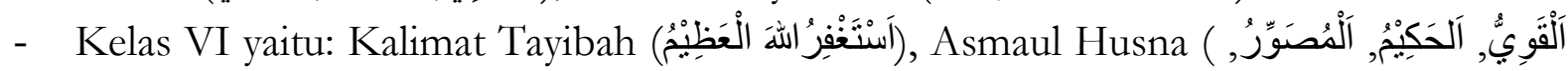
آلَقََدرُ Bijaksana, Sabar, Tobat, Akhlak terhadap Binatang dan Tumbuhan), Akhlak Tercela

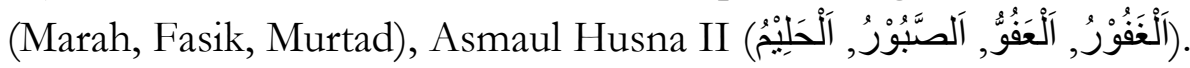

\section{Metode Pembelajaran Akidah Akhlak SD/MI}

Sebagaimana telah dijelaskan sebelumnya, metode adalah cara yang ditempuh oleh guru untuk mencapai tujuan pembelajaran. Dalam pendidikan Islam metode mempunyai kedudukan yang sangat penting untuk mencapai tujuan pembelajaran tersebut. Bahkan metode merupakan seni dalam mentransfer ilmu pengetahuan / materi pelajaran kepada peserta didik, bahkan dianggap lebih penting dibandingkan materi. Dalam sebuah ungkapan popular mengatakan bahwa "at-tariqat ahammu min al-maddah"(metode jauh lebih penting disbanding materi), adalah sebagai realita bahwa cara penyampaian yang komunikatif lebih disenangi oleh peserta didik walaupun sebenarnya materi yang disampaikan sesungguhnya tidak menarik. Sebalikya materi yang cukup baik, karena disampaikan dengan kurang menarik, maka materi itu sendiri kurang dapat dicerna oleh peserta didik. Oleh karena itu, penerapan metode yang tepat sangat mempengaruhi keberhasilan dalam proses belajar mengajar. Metode yang tidak tepat akan berakibat terhadap pemakaian waktu yang tidak efisien. Demikian juga halnya dalam pembelajaran akidah akhlak di MI/SD.

Materi akidah akhlak di MI/SD terdiri dari dua aspek, yaitu aspek akidah dan aspek akhlak. Seperti yang sudah dijelaskan pada pembahasan sebelumnya, aspek akidah berkisar tentang rukun iman, kalimat thayyibah dan asma'ul husnah. Jika diperhatikan, materi akidah tentang rukun iman lebih banyak pada muatan materi yang bersifat abstrak, contoh; beriman kepada Allah, SWT, beriman kepada malaikat, beriman pada rasul, beriman pada hari kiamat. Hal ini memerlukan metode yang tepat agar materi tersebut dapat dipahami oleh peserta didik.

Sedangkan salah satu karakteristik siswa MI/SD adalah baru mampu berpikir secara konkret, sedangkan materi akidah seperti yang dijelaskan di atas banyak yang bersifat abstrak. Walaupun materi tersebut bersifat abstrak, seorang guru harus menanamkan keyakinan pada siswa tentang adanya Allah, sementara Allah itu sendiri bersifat ghaib. Lalu bagaimana cara seorang guru menyampaikan materi yang bersifat abstrak tersebut? Mungkin salah satu cara yang bisa dilakukan guru adalah dengan cara menganalogikan sesuatu yang bersifat abstrak tersebut kepada sesuatu yang bersifat konkret. Cobtohnya: Allah itu ada tapi tidak Nampak, bisa dianalogikan seperti angin, angin itu ada dan kita bisa merasakannya, tapi dia tidak Nampak, 
Adapun metode pembelajaran akidah akhlak yang relevan dengan siswa MI/SD antara lain:

Metode Permainan Artikulasi

Permainan artikulasi yaitu permainan yang membuat siswa menjadi aktif dan berani mengutarakan pendapatnya, permainan ini memberikan ketrampilan berbicara dan berani tampil menyampaikan apa yang dipelajarinya. Permainan ini dilakukan secara berkelompok, dalam satu kelompok mencatat catatan-catatan kecil sambil mendengarkan sedangkan pasangannya menceritakan kembali yang baru diterima guru.

Permainan Mind Mapping

Permainan Mind Mapping sangat baik dilakukan untuk mengenal sampai sejauh mana pengetahuan siswa terhadap suatu materi atau pelajaran, dan juga sebagai alternatif jawaban dari hasil diskusi. Guru mengacak tiap kelompok untuk membaca hasil diskusi dan mencatat di papan tulis. (3). permainan melempar bola salju: permainan ini mewajibkan peserta didik untuk menjawab pertanyaan yang telah diberi kertas oleh guru kemudian dibentuk bola dan dilempar ketemannya secara halus.

Permainan kelompok bergerak

Dalam permainan ini siswa dituntut untuk berani mengungkapkan pendapat dan pandangannya dalam menganalisis suatu materi yang diajarkan.

Metode bercerita

Metode cerita sebagai alternative pada hampir semua pokok bahasan, karena selain aspek kognitif tujuan bidang studi ini adalah aspek afektif yang secara garis besar berupa tertanamnya akidah islam dan pengalamannya dalam kehidupan sehari-hari yang memiliki nilai-nilai akhlak yang mulia. Seperti contoh: kisah Luqman al Hakim dengan putranya, dimana seorang ayah mengajarkan akidah kepada putranya dengan bersyukur kepada Allah Swt, jangan syirik (menyekutukan) Allah Swt dan bersyukur kepada ayah dan ibu dengan berbakti atau tawadlu' kepada kedua orang tuanya.

Metode ceramah

Metode ceramah adalah metode pembelajaran yang dilakukan dengan menyampaikan pesan dan informasi secara satu arah lewat suara yang diterima melalui indera telinga. Metode ceramah disebut metode mau'idhoh hasanah dengan bilisan agar dapat menerima nasihat-nasihat atau pendidikan yang baik. Sepeerti yang dilakukan Nabi Muhammad Saw kepada umatnya, yaitu untuk beriman kepada Allah Swt dan Rasulullah Saw.

Metode Tanya jawab

Bertujuan agar anak didik memiliki kemampuan berfikir dan dapat mengembangkan pengetahuan yang berpangkal pada kecerdasan otak dan intelektualitas. Ini merupakan tujuan dalam aspek kognitif. Didalam pengajaran aqidah dapat dicontohkan, seperti: dialog atau tanya jawab antara Nabi Ibrahin as dengan umatnya. Dengan cara seperti itu akan menghasilkan nilai-nilai yang berhubungan tingkah laku. Dengan partisifasi aktif seseorang akan dapat menilai yang baik dan yang buruk dan kemudian dapat mengambil manfaat didalam kehidupan sehari-hari yang dapat mendatangkan kebaikan atau kebahagiaan. Penggunaan Tanya jawab bertujuan mengetahui sejauh mana tingkat pemahaman siswa 
terhadap materi pelajaran yang telah disampaikan oleh guru. Selain itu dengan adanya tanya jawab tersebut akan merangsang siswa untuk berfikir dan diberi kesempatan untuk mengajukan masalah yang belum dipahami.tersebut. Metode sosiodrama

Metode ini dapat digunakan dalam pokok bahasan: Adab disekolah,bakar Assidiq, Umar bin khatab, Bilal bin Rabbah dan lain sebagainya.

Metode demonstrasi

Metide demontrasi adalah penyajian bahan pelajaran oleh guru atau instruktur kepada siswa dengan menunjukkan urutan prosedur pembuatan sesuatu untuk mencapai tujuan pembelajaran. Metode demonstrasi dipergunakan dalam pokok bahasan: (a) Sifatsifat Allah dan sifat-sifat Rasulullah. (b) Akhlak terpuji, akhlak tercela dan sebagainya.

Metode bermain peran

Dipergunakan dalam pokok bahasan: (a) Berbakti kepada ayah dan ibu. (b) Adab makan dan minum. (c) Adab kepada guru, orang yang tua, teman dan sebagainya.

Demikianlah diantara metode-metode yang bisa menjadi pilihan bagi guru untuk diterapkan dalam pembelajaran akidah akhlak di MI/SD. Penggunaan metode-metode ini tentu juga tidak terlepas dengan kemampuan guru dalam menerapkan metode tersebut, karena suatu metode tidak akan bisa mengahsilkan pembelajaran yang efektif dan efisien, jika tidak didukung oleh kemampuan guru dalam menggunakannya.

\section{KESIMPULAN DAN SARAN}

\section{Kesimpulan}

Metode merupakan salah satu komponen yang sangat penting dalam pembelajaran, demikian juga dalam pembelajaran akidah akhlak MI/SD. Terutama materi akidah memerlukan metode yang khusus karena materi akidah banyak yang bersifat abstrak. Diantara metode yang relevan dengan bidang studi akidah akhlak MI/SD sebagai berikut: (1) Metode Permainan Artikulasi, (2) Permainan Mind Mapping, (3) permainan Melempar bola salju (4) permainan kelompok bergerak (5) Metode bercerita (6) Metode ceramah (7) Metode Tanya jawab (8) Metode sosiodrama (9) Metode demonstrasi (10) Metode bermain peran.

\section{REFERENSI}

Anisatul Mufarokah. (2009). Strategi Belajar Mengajar. Yogyakarta: TERAS

Anwar Arifin. (2003). Memahami Paradigma Baru Pendidikan Nasional dalam Undang-Undang Sisdiknas. Jakarta: Ditjen Kelembagaan Agama Islam Depag.

Armai Arif. (2002). Pengantar Ilmu dan Metodologi Pendidikan. Jakarta: CiputatPers. Bahasa.

Departemen Pendidikan Nasional. (2008). Kamus Bahasa Indonesia. Jakarta: Pusat

Djamaludin dan Abdullah Aly. (1999). Kapita Selekta Pendidikan Islam. Jakarta: Bumi Aksara.

Hamzah B. Uno. (2006). Perencanaan Pembelajaran. Jakarta: Bumi Aksara.

H.M Arifin. (2006). Ilmu Pendidikan Islam. Jakarta: Bumi Aksara. 
Muhaimin. (2011). Paradigma Pendidikan Islam: Upaya Mengaktifkan Pendidikan Agama Islam di Sekolah. Bandung: Remaja Rosda Karya.

keputusan Menteri Agama Republik Indonesia Nomor : 165 Tahun 2014 Tentang kemendikbud. (2013). Kurikulum 2013 Mata Pelajaran Pendidikan Agama Islam dan Bahasa Arab Pada Madrasah.

Pupuh Fathurrahman dan Sobri Sutikno. (2011). Strategi Belajar Mengajar. Bandung: PT. Refika Aditama.

Syaiful Bahri Djamarah dan Aswan Zain. (1997). Strategi Belajar Mengajar. Jakarta: Rineka Cipta.

Sholeh Hamid. (2014). Metode Edutainment. Jogjakarta: Penerbit DIVA Press.

http://missoul.mywapblog.com/karakteristik-anak-mi.xhtml\# ftn. diakses sabtu2609- 201514.35 wib. 